\title{
Social Security, Saving, and Wealth Accumulation
}

\author{
Daniel L. Thornton
}

$\sigma^{\circ}$ ocial Security is a publicly run, mandatory retirement program. A number of analysts have suggested that the program be privatized. I discuss here the difference between the current Social Security program and an effectively equivalent private program with respect to wealth accumulation and saving at the individual and national levels.

Under current law, Social Security requires each covered worker to pay into the program 12.4 percent of their taxable income (6.2 percent each from employee and employer). In return, those covered by Social Security receive payments that are determined by several factors, including age at retirement and the amount of payroll tax contributions made while working. In an essentially equivalent private program, the government could require each covered worker (and/or the employer) to pay into a private investment account 12.4 percent of their taxable income and prevent workers from accessing these accounts until they retired. In the private program, however, workers would own their accumulated contributions and earnings. That is, workers would accumulate wealth. Individuals would thereby have considerable flexibility. They could be given some discretion on how the funds are invested. Moreover, unlike the one-size-fits-all approach of Social Security, individuals could be given considerable discretion as to how the funds would be disbursed upon retirement. Those who were interested in providing their children with opportunities they never had might decide to work longer and pass all or most of their wealth to their heirs. Alternatively, individuals with relatively short life expectancies might opt to retire at the earliest possible date and/or disburse funds more quickly. In the event of an untimely death, the wealth accumulated in their account could be passed to their heirs or given to philanthropic causes. This flexibility could be particularly important to low- and moderateincome earners who may find it difficult to save beyond what they are required to contribute to Social Security. Private accounts would give these earners a greater opportunity to accumulate wealth that they could use at their discretion, which would provide them opportunities not available under the obligatory Social Security annuity.

Economists have long known that current consumption and investment - at both the individual and national levels-do not depend so much on current income as on permanent income, which is to say, wealth. It is difficult to estimate how much private wealth accumulation would have differed had Social Security been administered privately rather than publicly. However, the Social

Security trust fund balance-the accumulated Social Security tax receipts less Social Security payments plus earnings-at the end of 2004 was $\$ 1.68$ trillion, about two-fifths as large as the federal debt held by the public.

Whereas private savings are channeled through financial markets and ultimately lent to individuals, businesses, and governments - state, local, and federal-currently, the Social Security trust funds are not being allocated through competitive financial markets and are not earning a market-determined rate of return. Thus, unlike private saving, Social Security taxes are not directly available to finance private spending and investment.

This year's Social Security tax receipts are used to pay this year's Social Security benefits. In years when tax receipts are greater than benefits paid, Social Security experiences a surplus. If the surplus were used to reduce the national debt, the funds available for private consumption or investment would be essentially the same as under a private system. This has not been the case, however. Since the early 1980s, Social Security has been running a persistent surplus. Instead of reducing the national debt and, thereby, increasing the pool of funds available for private spending, most often Social Security surpluses have been used to fund "on-budget" deficit spending. This practice has had the effect of making the unified budget deficit smaller than would have been the case had Social Security been privately run. In reporting to Congress recently, Federal Reserve Chairman Greenspan noted that " $\mathrm{t}]$ he major attraction of personal or private accounts is that they can be constructed to be truly segregated from the unified budget and, therefore, are more likely to induce the federal government to take those actions that would reduce public dissaving and raise national saving." 1 The government would not be able to simply divert Social Security surpluses to cover on-budget deficits. Rather, it would have to compete in financial markets with private investors for private savings.

The extent to which fostering private wealth accumulation and increasing the flow of funds into competitive financial markets would promote economic growth or reduce the incentives for government borrowing (and spending) is difficult to say. Nevertheless, it is clear that the current system diverts funds from competitive financial markets and reduces the control that low- and moderate-income earners have over their retirement funds.

\footnotetext{
${ }^{1}$ Testimony of Chairman Alan Greenspan, Future of the Social Security Program and Economics of Retirement, before the Special Committee on Aging, U.S. Senate, March 15, 2005.
} 